\title{
Outcomes Assessment and Quality Enhancement through AACSB Business Accreditation: The Case of the University of Bahrain
}

\author{
Lobna Ali Al-Khalifa ${ }^{1}$ \\ ${ }^{1}$ Former Quality Assurance Director: College of Business, University of Bahrain, Sakhir, Kingdom of Bahrain \\ Correspondence: Lobna Ali Al-Khalifa, P.O. Box 30347, Manama, Kingdom of Bahrain \\ Received: February 18, 2016 \\ Accepted: March 1, 2016 \\ Online Published: March 6, 2016 \\ doi:10.5430/ijhe.v5n2p92 \\ URL: http://dx.doi.org/10.5430/ijhe.v5n2p92
}

\begin{abstract}
Assessment of students learning is a critical component of the accreditation process of the Association to Advance Collegiate Schools of Business (AACSB). There is also a general agreement that the most tangible benefits from AACSB accreditation result from the changes in the internal operations to bring the higher education institutions into compliance with its standards. While AACSB is the most sought after Business accreditation in the Arab region, there is very little written about AACSB accreditation and the challenges facing business colleges in meeting the standards related to outcomes assessment in this region. This paper aims to address this gap in the literature by discussing the case of the College of Business of the University of Bahrain. It considers some of the concerns raised in the existing literature and offers suggestions for other institutions involved in the accreditation process. It also examines the link found between outcomes assessment and quality in higher education as well as the challenges and opportunities of AACSB accreditation for the College of Business of the University of Bahrain.
\end{abstract}

Keywords: Outcomes assessment, Quality enhancement, AACSB Business Accreditation

\section{Introduction}

Currently the College of Business of the University of Bahrain is in process toward accreditation from AACSB. The most challenging part of achieving the accreditation is meeting the 2003 standards related to outcomes assessment. As Trifts (2012) pointed out outcomes assessment, in the 2003 revision of AACSB standards requires substantial effort and time for business colleges to meet these standards and to achieve accreditation, by placing emphasis on direct assessments of student learning. The 2013 standards allow more flexibility for business colleges to include indirect assessments as part of their collection of evidence to support continuous improvement. According to the 2003 standards, "schools should be demonstrating a high degree of maturity in terms of delineation of clear learning goals, implementation of outcome assessment processes, and demonstrated use of assessment information to improve curricula" (AACSB, 2012, p. 69). Developing and implementing outcomes assessment or assurance of learning (AoL) to meet AACSB revised standards of 2003 takes at least three or four years to develop learning goals and objectives and to create the metrics and rubrics needed to measure students' progress toward the goals and to address deficiencies (closing the loop). Similarly, the revised standards of 2013 suggests, "The school uses well-documented, systematic, processes for determining and revising degree program learning goals; designing, delivering, and improving degree program curricula to achieve learning goals; and demonstrating that degree programs learning goals have been met" (AACSB, 2013, p.5). Therefore, some business colleges have labored for 10 or more years to achieve AACSB accreditation.

The academic literature reflects the difficulties experienced by business colleges in meeting the AoL standards. Clinton, Marco and Chu (2009) distinguished between two main streams of academic literature concerning AACSB AoL standards. The first is the philosophical discussion of the potential positive and negative impacts of the AoL standards on universities, departments, professors, students, and other constituents. Marques and Garrett (2012) provided a brief evaluation on the ongoing debate about the pros/cons of AACSB AoL procedures. While, transparency, consistency and increased faculty cooperation are often cited as the advantages of the AoL, there are concerns related to the increasing reliance on quantitative measurements and standardized assessment tools. The second stream of the literature deals with the intent of the standards, aiming to clarify the AoL process to other members of the academe and how it can be implemented. Abdelsamad, Farmer, McNeil and Stevens (Summer 2015) provided a comprehensive comparison between 2003 and 2013 standards and offered suggestions for business institutions seeking initial accreditation. However, as, Rexeisen and Garrison (2013) pointed out most business 
colleges are still in the early stages of developing their closing the loop practices and processes and in many cases assurance of learning have led to minor interventions in some courses instead of major curricular changes. Rexeisen and Garrison (2014) also discussed some concerns related to faculty ownership of the AoL process. They explained that although AACSB views faculty engagement in outcomes assessment and closing the loop related activities to be critical to the AoL process, faculty often resist this process. This is because faculty often feel overloaded with activities to meet the requirements imposed by AACSB and other national or regional accreditation and quality assurance bodies and most importantly, most of them still do not believe that outcomes assessment leads to meaningful improvement in students learning.

In the context of Bahrain, the assessment of learning outcomes became a mean to evaluate the academic standards and the quality of programs offered by higher education institutions in 2009 by the National Authority for Qualifications and Quality Assurance of Education and Training. Nonetheless, most higher education institutions in Bahrain do not have the required knowledge to measure student achievements of learning outcomes as Almansoori's (2012) analysis of the findings of the review of several Business programs pointed out. The aim of this paper is to examine the link found between outcomes assessment and quality enhancement in higher education as well as the challenges and opportunities of AACSB accreditation for the University of Bahrain, with its current emphasis on outcomes assessment as a means to enhance quality in Business education. It also considers some of the concerns raised in the existing literature and offers suggestions for others involved in the AoL process. This paper is divided into three parts that focus, respectively, on quality in higher education, outcomes assessment and the case of the University of Bahrain. It advocates the continuous revision of the assessment process, the use of a combination of formative and summative assessment approaches and providing support to pedagogic research on outcomes assessment, which require high level of commitment from the institution leaders to spark interests in assessment and environmental change that is conductive to quality enhancement.

\section{Quality in Higher Education}

Quality in higher education can be seen from different angles. Dew (2009) identified five common ways to portray quality: endurance, luxury, value added, conformance and continuous improvement. Endurance is a quality that distinguishes between higher education institutions that persisted for long time and the newcomers with only few years of operation. Quality that is associated with luxury or prestige requires heavy investment in luxurious campuses, most up-to-date facilities, research and scholarships in order to attract the most promising new students and to push up ranking of the institution. Some higher education institutions use ranking as a proxy for quality and base their decisions on it despite the rising criticisms of the methodological flaws applied in some ranking systems, including the Shanghai Jiao Tong one. Critics often referred to the inability of these ranking methods to capture the variability among programs, the arbitrary weighting of different factors, the inclusion of reputational factors, and the heavy emphasis on research, neglecting the quality of teaching and learning (Green, 2011). The view of quality as value added was popular in the 1980s emphasizing the role of higher education in adding value to the consumer or society by improving students learning, social skills, social contacts, writing skills, reading skills, critical thinking, or other attributes that are consistent with the mission of the institution (Dew, 2009).

Some quality assurance agencies perceive quality as conformance to requirements. They specify a set of requirements that a college, university, or specific academic program is required to meet, and then review performance to see if there is conformance to the requirements. For these agencies, the primary goal is the accountability of higher education institutions to ensure the public of their compliance with certain quality criteria. Traditionally, the evaluation of institutional efficiency has been focused on what institutions have in terms of financial inputs and resources, but currently there has been a shift from evaluating inputs to outcomes (Liu, 2011). Conformance is one of the main two categories that conceptions of quality often fall into according to Kleijnen, Dolmans, Willems and Van Hout (2013). In the second category, quality is perceived as a process of enhancement and continuous improvement. This perception emerged with the shift from inputs to outcomes assessment, which is a widely used term that refers to assessments designed to measure student learning outcomes in higher education (Liu, 2011).

Currently, stakeholders at many levels as the government, quality assurance agencies, accrediting organizations, and the public place a stronger emphasis on outcomes assessment as a means to enhance the efficiency of the academic programs. Yet Jones and Wehlburg (2014) pointed out that faculty did not embrace this practice when outcomes assessment first became mandated, assuming these mandates would go away like several other trends in higher education regulations. They explained that "many faculty are grieving what they perceive as the lack of focus on teaching, seeing "accountability" mandates as useless and bureaucratic, designed only to satisfy legislatures" (p.17). 
Furthermore, the assessment of learning outcomes may show inadequacies to faculty, colleagues and senior managers, which might explain initial rejections. There is also a strong debate in the literature that quality in general is often perceived as a bureaucratic checking device by the teaching staff rather than a means to enhance teaching and learning and that higher education institutions are still more concerned with compliance, accountability and meeting basic standards (Kleijnen et al., 2013).

\section{Outcomes Assessment}

Assessment is defined as "a systematic, on-going, iterative process of monitoring a program or college to determine what is being done well and what needs improvement" (Otero \& Spurrier, 2005, p.5). Jones and Wehlburg (2014) distinguished between the assessment of learning outcomes and other traditional measures used by higher education institutions. These measures include graduation rates, employment statistics, graduate school admission numbers, and student/employer/alumni satisfaction survey results. They argued that the assessment of learning outcomes are more effective than all the other traditional measures of higher education in planning for the continuous course/program improvement which is critical to the success of students and institutions. More recently, experts distinguished between direct and indirect measures and their relative utility in assessing learning outcomes (Calderón, 2013). Indirect assessment is mainly based upon opinions of students, alumni and employers, through surveys, focus groups and exit interviews which report their perceptions of students learning as supported by the programs and services provided to students and how this learning is valued by them. Direct assessment is based on a sample of actual students work, including class projects, exams, oral presentations and case analysis that demonstrate the knowledge and skills of the students and provide strong evidence of their learning (Martell and Calderon, 2005).

Learning outcomes among other terms are often used in the education literature and by national qualifications frameworks to address content knowledge in given areas, skills (application of knowledge, cognitive and practical), and students attributes that go beyond the disciplinary expertise or technical knowledge (Liu, 2011). According to Dzelalija and Balkovic (2014), "learning outcomes denotes positively assess knowledge and skills by a competent body, in accordance with the competence (autonomy and responsibility), which a learner has achieved through learning and proves after learning process" (p.155). They based their definition on the European Qualification framework (EQF). EQF, as well as other national and transnational qualifications frameworks, operating in approximately 142 countries, set the learning outcomes required for certain degrees at the national level (Dzelalija \& Balkovic, 2014).

Hartel and Foegeding (2004) distinguished between outcomes, competencies and objectives. They wrote, "The main distinction between objective or competency and a true learning outcome is that a learning outcome is written so that it can be measured or assessed" (p. 69). They defined objectives as very general statements about the ultimate aims of a course or a program and competencies as general statements that list the anticipated knowledge and skills of students graduating from a particular program (p.69). They also explained that a competency may have several learning outcomes, which are specific measurable statements describing what students will be able to do upon the completion of a course or graduation from a program. Since 2000, European and American universities have developed competencies associated with various degree levels in different academic fields (Green, 2011). Some universities also use graduate attributes as orienting statements of education objectives to inform curriculum design and the provision of learning in the different academic programs (Sin \& McGuigan, 2013).

The American Association of Higher Education (AAHE) has driven the outcomes assessment movement requiring American accrediting agencies to embrace outcomes assessments in their accreditation requirements since the 1980s (Sampson \& Betters-Reed, 2008). Some of these agencies namely ABET (Accreditation Board for Engineering and Technology) and AACSB International are highly active in accrediting beyond US borders and their accreditation process is centered on the outcomes-based model that has been phased in for the accreditation of US programs (Green, 2011). The European Quality Improvement System (EQUIS) competes with AACSB across borders. By 2011, EQUIS had accredited 128 institutions in 36 countries, including the United States, while there were 620 institutions that held AACSB accreditation, including 484 business schools in the United States and 136 internationally (Trifts, 2012; Green, 2011). In the Arab Region, AACSB accreditation is more prominent. In an interview with John J. Fernandes the former president and the chief executive officer of AACSB International, he said, "AACSB accreditation demonstrates that a business school has achieved overall high quality and is committed to students learning and continuous improvement" (Hodgson \& Clausen, 2012, p. 739). He also stressed that the Arab region is important for AACSB and that countries within this region will have greater need for highly qualified business graduates as they continue to develop their businesses. By 2012, eight universities in this region were accredited by AACSB namely: the American University of Cairo, Kuwait University, American University of Beirut, 
Qatar University, King Fahad University, American University of Sharjah, United Arab Emirates University, and University of Dubai (Hodgson \& Clausen, 2012).

The academic literature supports the emphasis of higher education legislators and accrediting agencies on outcomes assessment. Rodgers, Grays, Fulcher and Jurich (2013) argued that "regardless of the orientation, whether for accountability or for program improvement, assessment should provide a systematic process for the faculty and institutions to make informed decisions about students learning" and "by assessing learning outcomes, faculty members can identify aspects within their curriculum to be modified or retained based on results" (p.384). Jones and Wehlburg (2014) also wrote, "When faculty and the community can see the data about students learning and discover what and how students are learning, they experience a transformational moment" (p.21).

\section{The Case of the University of Bahrain}

The University of Bahrain is one of the two public higher education institutions in the Kingdom of Bahrain. The roots of the University go back to the late sixties when Bahrain established the Higher Institutes for male and female teachers. These Institutes later developed into the University College of Arts, Sciences, and Education in 1978. In 1968, the Gulf Technical College was also established and was later renamed the Gulf Polytechnic in 1981. On $24^{\text {th }}$ May, 1986, the University of Bahrain was established by merging the Gulf Polytechnic and the University College of Arts, Sciences and Education. On $18^{\text {th }}$ April, 1999, the University of Bahrain was reorganized to its current form comprising the following Colleges: Applied Studies, Arts, Business, Education, Engineering, Information Technology, Law and Sciences. Additionally, there are one regional university (Arabian Gulf University), which was established in 1984, and ten private higher education institutions that were established following the liberalization of the higher education sector in 2001.

The Second public higher education institution is Bahrain Polytechnic, which was recently established in 2008 as one of the initiatives taken by the Kingdom to reform education since 2001. Other initiatives included the Higher Education Strategy, the National Qualifications Framework, and the Quality Assurance Authority for Education \& Training, now the National Authority for Qualifications and Quality Assurance for Education \& Training (QQA). QQA was established in 2009 and used outcomes assessment as a means to evaluate the academic standards and the quality of programs offered by higher education institutions. The British Council and the Regional Bureau for Arab States of the United Nations Development Program have funded a series of projects related to quality assurance that have fostered a pool of indigenous quality evaluators whose the Kingdom of Bahrain is currently relying upon to support their education reforms since 2001 (Al-Khalifa, 2015; Al-Alawi, Al-Kaabi, Rashdan \& Alkhalifa, 2009).

In conformance with the QQA standards, the University of Bahrain puts emphasis on outcomes assessment at both the course and the program levels. The University quality assurance units have three main areas of responsibility compliance with national standards, outcomes assessment and international accreditation. The University aimed to increase the percentage of its internationally accredited and successfully reviewed programs from $20 \%$ to $70 \%$ in its 5years strategic plan of 2009-2014 (University of Bahrain, 2009). In 2011, the AACSB have approved the eligibility applications of the College of Business of the University of Bahrain for the overall business curriculum and the Accounting Program. Later the College decided to proceed only with Business Accreditation, which is the prevailing pathway in AACSB accreditation. Despite the University emphasis on outcomes assessment, the gap analysis that examined the College of Business performance against each AACSB standard in 2012 identified deficiencies in meeting the AoL standards as well as the standards on faculty qualifications.

The standards of 2003 on the proportion of academically qualified and professionally qualified faculty that must be at least $90 \%$ (with a 50\% threshold for academically qualified status) in the College as a whole and in each separate program do not constitute impediments to AACSB accreditation in the case of the College of Business. The vast majority of faculty members possess a research doctoral degree. Several faculty reengaged in research to gain academically qualified status and to ensure the renewal of their contracts. Furthermore, the revised standards of 2013 are more lenient. Under these standards, there are four categories for specifying qualified faculty status, which are Scholarly Academics, Practice Academics, Scholarly Practitioners and Instructional Practitioners. These statuses are based on initial academic credentials, initial professional experience, and sustained academic and professional engagement. Scholarly Academics is equivalent to academically qualified status and there is a $40 \%$ threshold for this category and $60 \%$ for Scholarly Academics, Practice Academics and Scholarly Practitioners. The new standards allow the College of Business some flexibility in hiring new faculty in the field of accounting in particular. The shortage of candidates with research doctorates in accounting is well documented and there is a growing recognition of the practical experience value that practitioners can bring to the students experience. 
The College of Business benefited from the appointed of an academic mentor from AACSB that provided one on one guidance and insights about similar challenges other colleges facing in meeting AoL standards. Student selection is one of the three approaches suggested by the AACSB (2003) to ensure students learning. The College of Business adopts this approach only at the MBA level to support the program's requirements of knowledge and skills by testing prior knowledge and skills before admitting students to this program. The second approach is course embedded measures which are conducted midway through the programs and known as formative assessment. It includes instruments such as assignments, tests, quizzes, oral presentations and projects. Comprehensive exams and capstone projects are instruments used in the third approach of AoL, which provide summative data on students learning upon the completion of the program. The College of Business did not consider using the third approach, although capstone projects can be successfully used to access the learning outcomes of the MBA programs as Gray, Boasson, Carson and Chakraborty (2015) pointed out. They wrote that, "These summative assessments are to provide stakeholders such as faculty and administrators with a snap shot of students learning as a result of a culminating course experiences within the programs. Instead of a single writing project or oral presentation that may be covered in a specific course, these assessments yield areas within the curriculum where students are either flourishing or struggling within a program" (p.3).

AACSB also accepts the use of tests such as the Major Field Test in Business (MFTB) for AoL assessment. MFTB consists of 120 multiple choice questions, covering commons body of knowledge in key business areas such as Accounting, Economics, Management, Quantitative Business Analysis, Marketing and Finance. MFTB was developed by the Educational Testing Service (ETS) for students in the last year in their undergraduate business programs and widely used by AACSB accredited and non-accredited colleges in the United States. The preparation for the test can help the College to improve the curriculum and the results have the potential to be comparable across business colleges, which provide stakeholders with solid evidence on students learning and whether students learn more in some colleges than others (Liu, 2011). These tests also allow faculty members to use their time to focus on other aspects of AACSB accreditation. Yet the validity of such tests is often questioned in assessing students learning and providing useful insight into changes in the curriculum that can improve students learning and support closing the loop efforts (Green, Stone, \& Zegeye, 2014). Furthermore, the use of course embedded assessments is often recommended. Jones and Wehlburg (2014) discussed the benefits that result from course embedded assessment of learning outcomes such as the empowerment of faculty by giving them a voice in the course/program redesign and discovering new collaborative partners in the assessment taskforce community. There is also a growing body of the literature on course embedded assessment applications (e.g. Sampson \& Betters-Reed, 2008; Santos, Hu, \& Jordan, 2014).

Since some of the best practices for closing the loop have taken both direct and indirect measures, the College of Business assessment schemes involve stakeholders, advisory boards, and alumni. Course embedded assessments were used as direct measures of learning outcomes despite the initial resistance of faculty that felt overloaded with activities to meet AACSB standards related to faculty qualifications and other quality assurance related requirements. Unfortunately, quality in general also is still perceived by most faculty as a bureaucratic checking device rather than a means to enhance teaching and learning, which led to a delay in the assessment of learning outcomes at the courses and the programs levels. As, Almansouri (2012) pointed out, business programs were developed without learning outcomes and faculty members did not have the required knowledge to measure students achievement of learning outcomes. It is also important to refer to the absence of a "culture of assessment" in the College. Leadership, faculty involvement, resources, student participation, and data collection are essential to form this culture as Rodgers, Grays, Fulcher, and Jurich (2013) pointed out.

The AoL process of the College of Business was initially driven by the Quality Assurance Committee during the academic year of 2012-2013. A faculty member from each program was nominated by the department Chair to participate in this committee. For the most part the committee served as a self-managed team, headed by the Quality Assurance Director. As a start, the Quality Assurance Committee carried out the following tasks:

- The allocation of duties and responsibility of all participants in the assurance of learning process. The College Council headed by the Dean was given the final authority in the AoL process and recommendations for the College to ensure the consistency of the recommendations of the Quality Assurance Committee with the goals and objectives of the University as well as the strategic goals of the College. The Quality Assurance Committee carried the responsibility of the review of the assurance of learning process for all the programs offered by the College. 
- The development of an assessment plan to portray the roadmap to organize AoL practices for the MBA and undergraduate programs. This was carried out to meet AACSB expectations regarding proper practices of assurance of learning that focus on the learning goals (outcomes) at the program-level. The College had defined one set of learning goals for all its undergraduate programs because they have a common framework for general knowledge and skills (a common core).

- The revision of the programs' goals to ensure their compliance with AACSB 2003 Standards in terms of general knowledge and skills at different programs levels, that students will carry them into their careers such as communications abilities, problem-solving abilities and reasoning skills. Learning outcomes should also include expectations for learning accomplishment in areas that directly relate to management tasks and form the business portion of degree such as accounting, management science, marketing, human resources and operations management. Since the College is only seeking AACSB business program certification, there are no curriculum suggestions to its accounting major.

- The use of formative assessments to directly measure students learning in specific courses. Each learning goal was translated into one or more learning objectives and criteria - also known as key performance indicators for judging whether or not students achieve the learning goal. This approach extends beyond the routine use of tests and exams grades, requiring faculty to use rubrics in the evaluation of student performance. Rubrics faculty used in the assessment were based on models available online and in printed materials, but they were not exempted from changes and modifications to capture more accurately the work in the classroom. Figure 1 depicts the AoL process.

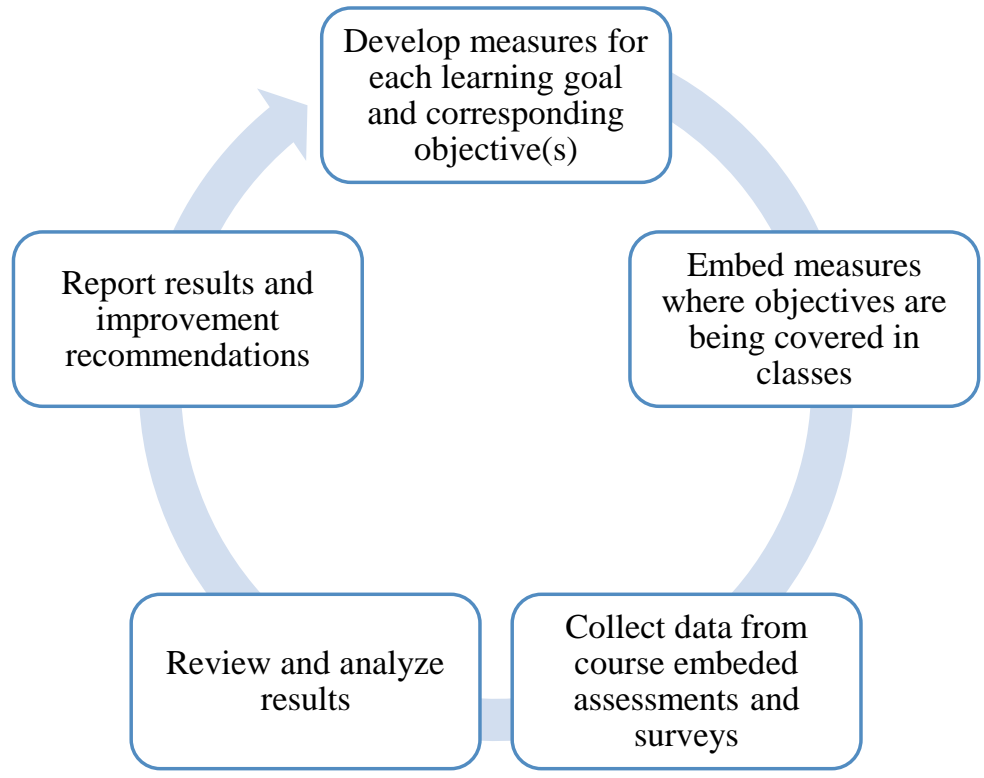

Figure 1. AoL Process for Assessment and Recommendations

Formative assessments were conducted following the identification and the matching of the learning goals and objectives intended to be measured with the course objectives. This assessment approach led to some revisions in the content of college requirement courses for undergraduate programs in order to link these courses to all functional areas of business and to show the importance of decision making in organizations. The content of some courses were also revised at the graduate level. Yet faculty members often questioned the reliability of this approach because the observations made hinged on the individual faculty member and the assessed sample of students. Formative assessments were also criticized for not providing data for comparative use. Furthermore, several faculty members also preferred the summative approach by relying on major field tests in the Business discipline for the undergraduate programs. It is obvious that these tests can complement the College efforts in assessing learning outcomes in both content mastery and performance of skills such as problem solving and critical thinking. Specialized accreditation reviews are also increasingly advocating a combination of the formative and summative assessment approaches (Dew, 2009).

Although changes in the assessment process do not constitute a closing of the loop actions (Rexeisen \& Garrison, 2013), continuous revision of the process and supporting pedagogic research on outcomes assessment are crucial for 
the College to get better results and making more informed decisions that improve students learning. As Rodgers, Grays, Fulcher and Jurich (2013) pointed out "when a low quality or "bad form" of assessment is practiced, much effort is exerted with little benefit" (p.385). They also clarified that "faculty members who only experience poor assessment develop resistance to it" and "if faculty members begin to see that assessment gives them insight into students learning and their impact on it, then it is much easier to embrace" (p.385). The consultation of assessment specialists and the continuous revision of the formative assessment would allow the College to adopt more effective course embedded measures. Major field tests should also be considered to supplement the assessment process.

Moreover, good leadership is vital to spark interest in assessment throughout the College and environmental change that is conductive to quality enhancement and continuous improvement. Quality leaders as Daft and Lane (2005) pointed out "build whole organizations as communities of shared purpose and direction" instead of "relying on hierarchical control" (p.25). Dew (2009) also wrote, "Change in leadership is one of the most clearly understood factors in both the decline and improvement of quality, and in how an organization decides to focus on quality in all sectors" (p.8). Leaders who perceive quality as bureaucratic checking devise rather than a means to enhance teaching and learning are more concerned with compliance, accountability and meeting basic standards and the assessment of learning in this case is likely to lead to minor interventions. With the fast changes in higher education, leadership has received more attention in recent years. Morris (2012) argued that all higher education institutions are facing shortage in quality leaders as many capable leaders choose not to pursue an administrative position and in the absence of leadership development initiatives.

In addition, the University emphasis on international accreditation may increase the likelihood of seeing accreditation as an end in itself which may lead as Davies (2015) pointed out to "heightening managerial belief in the reputational importance of achieving/maintaining accreditation" (p.109). He explained that if managers place more emphasis on the reputational importance of achieving and maintaining accreditation, this would lead to "perfunctory compliance" rather than "active cooperative involvement" by faculty members, which further strengthens the already negative perception of the effectiveness of outcomes assessment. Therefore, accreditation should be treated "as an agent of beneficial change, which, in turn, induces greater managerial commitment to learning and teaching practices and processes required to meet accreditation standards" (Davies, 2015, p. 108).

Finally, although, AACSB have approved the eligibility application of the College of Business for the Accounting Program, the College decided to proceed only with Business Accreditation. The Accounting Program offered by the College is much sought after by business students in Bahrain. This program was the focus of one of the projects that were carried out by the Regional Bureau for Arab States of the United Nations Development Program. These projects aimed to review academic programs and to build a regional database that provides detailed comparable indicators of programs, staffs and cumulative finances of the leading private and public Arab universities. The overall academic standards of the reviewed business programs were judged to be good in the University of Bahrain and Abdel Malek Al-Saadi University of Morocco, and satisfactory in all the other participating universities except four of the others, which were deemed to be unsatisfactory (UNDP/BRAS, 2005). The Accounting Program would further benefit from AACSB curriculum suggestions specific to accounting majors. AACSB Accounting Standards list eleven learning outcomes that any accounting student should achieve, including knowledge and skills related to internal controls, project management, taxation of individuals and enterprises, international accounting issues, the ethical and regulatory environment and information technology skills, including data mining, analytics, and storage (Krom \& Buchholz, 2014). Furthermore, earning AACSB accreditation for the overall business curriculum as well as the Accounting Program would not only enhance the national, regional and international recognition of the College of Business, it would also give the College "access to, and facilitation of, international benchmarking and innovation in teaching and learning, research and scholarship" (Hodgson \& Clausen, 2012, p. 739).

\section{Conclusion}

AACSB accreditation is much sought after by business colleges in the Arab region. While meeting the AoL standards is the most challenging task especially for colleges seeking initial accreditation and in the absence of an assessment culture. The College of Business of the University of Bahrain relies mainly on formative assessment that consists of establishing program goals and objectives, choosing instruments (e.g., oral presentations, essays, tests), assembling and examining data, and finally using results to improve students learning in its academic programs. The addition of major field tests would also complement the AoL process by assessing content mastery and performance of skills and by providing data for comparative use at the undergraduate level. MBA capstone projects can also provide the College with useful summative data that can be used to improve students learning in this program. The continuous revision of the AoL process and supporting pedagogic research on outcomes assessment would improve 
the quality of results. This requires high level of commitment from the institution leaders to spark interests in assessment and environmental change that is conductive to quality enhancement and continuous improvement. Yet the level of commitment depends on the type leadership exercised within the higher education institutions and their perception of quality as well as the ultimate aim that underlie their pursuit of accreditation which are the main factors that would determine the extent and breadth of benefits from AACSB accreditation.

\section{References}

Abdelsamad, M.H., Farmer, B., McNeil, R., \& Stevens, G. (Summer 2015). Major Changes in AACSB Standards (2003 Compared to 2013). S.A.M. Advanced Management Journal, 80(3), 4-11 https://www.highbeam.com/doc/1G1-432064501.html

Al-Alawi, Y., Al-Kaabi, D, Rashdan, S., \& Al-Khalifa, L. (2009). Quality Assurance and Continuous Improvement: A Case Study of the University of Bahrain. Quality in Higher Education, 15(1), 61-69. http://dx.doi.org/10.1080/13538320902731575

Al-Khalifa, L. (2015). Benchmarking as a Means to Gauge and Improve Academic Standards in Higher Education within the Arab Region. International Journal of Higher Education Management, 2(1), 52- 62. http://www.ijhem.abrmr.com

Almansoori, W. A. (2012). Learning Outcomes in External Programme Reviews: A case Study from Bahrain. The Independent Journal of Teaching and Learning, 7, 46-54.

Association to Advance Collegiate Schools of Business (AACSB). (2012). International eligibility procedures and accreditation standards for business accreditation. Retrieved from http://www.aacsb.edu/accreditation/standards-busn-jan2012.pdf

Association to Advance Collegiate Schools of Business (AACSB). (2013, May 3). AACSB assurance of learning standards: an interpretation. White Paper No 3. Issued by AACSB International Coordinating Committee and AACSB International Accreditation Quality Committee

Calderón, O. (2013). Direct and Indirect Measures of Learning Outcomes in an MSW Program: What Do We Actually Measure? Journal of Social Work Education, 49, 408-419. http://dx.doi.org/10.1080/10437797.2013.796767

Clinton, S. R., Marco, G., \& Chu, Y. (2009). Two Years into the Journey: AACSB Assessment of Learning in a "Principles of Marketing" Course. American Journal of Business Education, 2(4), 37-54. http://dx.doi.org/10.19030/ajbe.v2i4.4058

Daft, R. L., \& Lane, P. G. (2005). The leadership experience. Mason, Ohio: Thomson/South-Western.

Davies, J. (2015). Exploring issues in change management: Developing a systems perspective on the management of learning and teaching initiatives. The Business and Management Review, 6(5), 101-115. http://www.ijhem.abrmr.com

Dew, J. (2009). Quality Issues in Higher Education. Journal for Quality and Participation, April, 4-9

Gray, D. M., Boasson, V., Carson, M., \& Chakraborty, D. (2015). Anatomy of an MBA Program Capstone Project Assessment Measure for AACSB Accreditation. International Journal of Business Administration, 6(1), 1-7

Green, J., Stone, C., \& Zegeye, A. (2014). The Major Field Test in Business: A Solution to the Problem of Assurance of Learning Assessment? Journal of Education for Business, 89, 20-26. http://dx.doi.org/10.1080/08832323.2012.749206

Green, M.F. (2011). Lost in Translation: Degree Definition and Quality in a Globalized World. Change, September/October, 18-27. http://dx.doi.org/10.1080/00091383.2011.599288

Hartel, R.W., \& Foegeding, E.A (2004). Learning: Objectives, Competencies, or Outcomes? Journal of Food Science Education, 3, 69-70. http://dx.doi.org/10.1111/j.1541-4329.2004.tb00047.x

Hodgson, S., \& Clausen, T. (2012). Business Education Accreditation in the Middle East and North Africa: An Interview with John Fernandes of AACSB. Academy of Management Learning \& Education, 11(4), 736-743. http://dx.doi.org/10.5465/amle.2011.0537

Jones, B.M. \& Wehlburg, C.M. (2014). Learning Outcomes Assessment Misunderstood: Glass Half-Empty or Half-Full. Journal of the National Collegiate Honors Council; Fall/Winter, 15(2), 15-23. 
Kleijnen. J., Dolmans, D., Willems, J., \& Van Hout, H. (2013). Teachers' conceptions of quality and organisational values in higher education: compliance or enhancement? Assessment \& Evaluation in Higher Education, 31(2), 152-166. http://dx.doi.org/10.1080/02602938.2011.611590

Krom, C. L., \& Buchholz, A. K. (August, 2014). Understanding the New AACSB Standards. The CPA Journal, 58-61.

Liu, O. L. (2011). Outcomes Assessment in Higher Education: Challenges and Future Research in the Context of Voluntary System of Accountability. Educational Measurement: Issues and Practice, 30(3), 2-9. http://dx.doi.org/10.1111/j.1745-3992.2011.00206.x

Marques, J., \& Garrett, N. (2012). Implementing Mission-Driven Assurance of Learning: Improving Performance through Constructive Collaboration. Journal of Education Business, 87(4), 214-222. http://dx.doi.org/10.1080/08832323.2011.593588

Martell, K., \& Calderon, T.G. (2005). Assessment of Student Learning in Business Schools: Best Practices Each Step of the Way, Tallahassee, FL: Association for Institutional Research.

Morris, A. (2012). Perspectives and Thoughts on Leadership Development in Higher Education. E-Journal of Organizational Learning and Leadership, 10(1), 33-36.

Otero, R., \& Spurrier, R. (2005). Assessing and Evaluating Honors Programs and Honors Colleges. Lincoln, NE: National Collegiate Honors Council. http://digitalcommons.unl.edu/cgi/viewcontent.cgi? article $=1009 \&$ context $=$ nchcmono

Rexeisen, R. J., \& Garrison, M. J. (2014). Faculty Ownership of the Assurance of Learning Process: Determinants of Faculty Engagement and Continuing Challenges, Journal of Education for Business, 89, 84-89. http://dx.doi.org/10.1080/08832323.2012.761171

Rexeisen, R. J., \& Garrison, M. J. (2013). Closing the Loop in Assurance of Learning Programs: Current Practices and Future Challenges, Journal of Education for Business, 88, 280-285. http://dx.doi.org/10.1080/08832323.2012.697929

Rodgers, M., Grays, M. P., Fulcher, K. H., \& Jurich, D. P. (2013). Improving Academic Program Assessment: A Mixed Methods Study. Innovative Higher Education, 38, 383-395. http://dx.doi.org/10.1007/s10755-012-9245-9

Sampson, S.D., \& Betters-Reed, B.L (2008). Assurance of Learning and outcomes Assessment. A Case Study of Assessment of a Marketing Curriculum. Marketing Education Review, 18(3), 25-36. http://dx.doi.org/10.1080/10528008.2008.11489045

Santos, M. R. Hu, A., \& Jordan, D. (2014). Incorporating Multiple-Choice Questions Into an AACSB Assurance of Learning Process: A Course-Embedded Assessment Application to an Introductory Finance Course. Journal of Education for Business, 89, 71-76. http://dx.doi.org/10.1080/08832323.2012.757542

Sin, S., \& McGuigan, N. (2013). Fit for Purpose: A Framework for Developing and Assessing Complex Graduate Attributes in a Changing Higher Education Environment. Accounting Education: an international journal, 22(6), 522-543. http://dx.doi.org/10.1080/09639284.2013.847320

Trifts, J. W. (2012). The Direct and Indirect Benefits and Costs of AACSB Accreditation. SAM Advanced Management Journal, 20-27.

University of Bahrain (2009). University of Bahrain Strategic Plan 2009-2014. Retrieved from http://www.uob.edu.bh/uob_files/312/strategic-plan.pdf 